\title{
Silence, Motifs and Echoes: Acts of Listening in Postcolonial Hamburg
}

\author{
Katharina Kellermann
}

There is a strong movement in Hamburg 'Recht auf Stadt' ['Right to the City'] which, of course, also implies the understanding that the city is for the many. Who defines the city? Who defines the culture of remembrance in the city? Is this culture of remembrance always top-down-politics or are there other forms, too?

Political communities, such as cities, emerge in part through their approach to their own history. The question of citizenship is therefore always connected to a culture of remembrance. This question is particularly pertinent in the case of Hamburg, a city which, 'as a gateway to the world for the German Empire played a key role in the colonization of Africa' (Möhle et al. 2006, p. 7). Which perspectives on this colonial legacy are represented in the public discourse is always a matter of political contestation.

Presently, the urban space of Hamburg shows traces of colonialism, most of which are hard to clearly identify as such. They can be found within city planning in the form of architecture, street names and monuments, within cultural institutions, where knowledge is made apparent, as well as in the political discourses that shape the public discussions.

\footnotetext{
K. Kellermann $(\bowtie)$

Graduate Program Performing Citizenship, HafenCity University Hamburg, Hamburg, Germany

(C) The Author(s) 2019

P. Hildebrandt et al. (eds.), Performing Citizenship, Performance Philosophy, https://doi.org/10.1007/978-3-319-97502-3_7
} 
Following Pierre Nora, such historic traces can serve as sites of memory (Nora 2010, p. x), since they contribute to the formation of identities and are therefore constitutive of the urban community. In this sense, the debate on colonial history - as it is being held in Hamburg and many other major European cities - can serve as an example for the constitutive nexus of citizenship and culture of remembrance. The political and cultural manner by which these sites of remembrance are being handled, especially in a postcolonial and post-fascist Germany, is crucial for debates and modes on participation and exclusion. For example, in 2014 in Hamburg the Senate, in its paper 'Coming to Terms with the Colonial Legacy - a New Start for the Culture of Remembrance' (https://hhpostkolonial.files.wordpress.com/2014/07/senatsbericht-kolonialeserbe2014.pdf), proposed a variety of ideas for dealing with the city's colonial vestiges. Grassroots organizations and communities from former colonized countries subsequently criticized the paper in an open letter because it completely failed to take their own knowledge production, their experiences, expertise and points of view into consideration (http://www. hamburg-postkolonial.de/PDF/PM_NOTWITHOUTUS.pdf).

This question of which perspectives on historic events are being represented and whose narrative is being heard in this debate ${ }^{2}$ is not solely of symbolic meaning. The matter of the social positioning of the relevant agents-in terms of who is able to speak for themselves and who is privileged to speak for and about others-is rather just as much part of the city's memoryscape as the material traces remaining in the urban space and the colonial continuities in the public discourse. Urban space with its historic dimensions is constituted by a specific 'distribution of the sensible' (Ranciere 2004), in which acoustic materializations-such as 'acts of speech' and voices, but also sounds, music and atmospheres-mark social actions and influence individual and collective imaginations of the city. Accordingly, a critical social and artistic analysis of postcolonial cultures of remembrance should also take into account that urban memoryscapes are not solely materialized, for example, in the form of architecture, street names or monuments; they also have specific acoustic materiality.

In the following, the classic concept of the term soundscape is explored. Using examples from the artistic research project How to Hear the Invisible (How to Hear the Invisible-an acoustic map of the postcolonial memoryscape of Hamburg - is the artistic part of my research project 'Citizenship and Politics of Remembrance. Sound as a commemorative cultural medium in postcolonial Hamburg' in the framework of the graduate 
school Performing Citizenship. http://performingcitizenship.de/data/ katharina-kellermann-forschungsprojekt/), the project deals with the city as an acoustic space that displays itself as a sonic realm of urban, social and political experience and maps its soundscape as a space of remembrance. Referring to three soundtracks of the project-individually named: 'Silence', 'Motif' and 'Echo'-I show, through artistic work with sound, how the realm of the acoustic can function, beyond its perceptive intent, as an epistemological tool within the context of postcolonial culture of remembrance. Finally, I will outline the concept of 'acts of listening' and the implications for acoustic forms of remembrance, as well as the potential for sound as a medium of performative historiography.

\section{The Artistic Research Project www.how-to-Hear- THE-INVISIBLE.ORG}

According to Henri Lefebvre, the city is constituted by a variety of representations, imaginations and practices (Lefebvre 1991). These representations frequently have an acoustic dimension that I will take into account by analysing the city as a soundscape. My artistic research is based specifically on the classic notion of the soundscape-as developed by the Canadian composer and author R. Murray Schafer-following the work of Brandon LaBelle and paying attention to 'auditory figures' (La Belle 2010 , p. 25). Schafer's concept of the soundscape analyses the variety of sounds that arise from an environment as well as the listeners' perception of them. In his work, he focusses on the so-called Lofi Soundscapes (Schafer 1977, p. 97) - that consist of the congestion of industrial and electronical noise. In focusing on these soundscapes, there is an emphasis on the experience of 'sound pollution' (Schafer 1977, p. 97). However, the project of How to Hear the Invisible artistically encounters the soundscape with an acoustic approach, based on the ways in which sound and voices operate in everyday life, and also in terms of narrative. In addition, there is focus on the cultural, political and social significance of auditory figures:

Which motifs repeat?

Where is silence?

What echoes?

By answering these questions, the project endeavours to enable an acoustic experience that locates and dislocates remembering through 
sound. In various sound tracks, ${ }^{3}$ Hamburg's daily urban soundscape is augmented through new sounds and voices. 'Motif', 'Silence' and 'Echo' serve as formal structures for the production of sound material (interviews, samples, compositions, field recordings), as well as featuring in the editing and montage. They mark places, like the Rothesoodstrasse and Hafencity and draw - in form and content-a connection from colonialism to post- and neo-colonialism within Hamburg's urban space. Likewise, these tracks are used as metaphors to describe postcolonial debates around the general lack of representation of anti-colonial resistance in the urban space and public discourse. For example, the famous pan-Africanist George Padmore organized the first conference of the International Trade Union Committee for Black Workers in Hamburg in 1930, and was head of the organization's office in Rothesood Strasse in Hamburg, till it was closed by the Nazis in 1933 (Möhle et al. 2006). The missing reference to his legislating at the place of his former office can be described as silence. Similarly, the tendencies of romanticizing colonialism by using its context (through references on colonial emperors and so-called colonial goods) in contemporary issues like urban planning in the Hafencity can be described as a neo-colonial echo. In this way, 'Motif', 'Silence' and 'Echo'-the titles of the tracks-also function as auditory figures, depicting how colonial history affects the contemporary daily life of the city and its people today.

The project thus explores which acoustic dimensions the (unmarked, and therefore seemingly mute) colonial traces of Hamburg's urban spaces may have. The montage searches for a possibility to make them audiblehistorical connections, continuities and contemporary references being rearranged through sound. By layering and mixing a variety of sounds, voices, vibes and atmospheres, the project tries to map the postcolonial city as an acoustic space, focusing on political functions and perceptive modes of operation of sounds and voices within that space. The function of the auditory figures - the respectively acoustic materials and montage that are developed in order to enhance a possibly, different imagination of the postcolonial city through a shifting, editing and alienating of the material-is now discussed for the tracks 'Motif', 'Silence' and 'Echo'.

\section{Motifs}

Acoustic motifs structure our sonic memory. Their repetition and variation are the basis for processes of remembrance, as well as for spatial 
imagination. In Hamburg, such motifs also serve as signature sounds for the city's self-promotion as a cosmopolitan metropolis and 'gateway to the world'. Horns, ship engines and screeching seagulls are typically representative of the city's soundscape, and thereby trigger strong associations. However, they do not only sound on-site, but are also being used to aestheticize and brand other spaces, for example, the subway station at Hafencity University. These selected and edited sounds serve to fabricate the image of the new district of Hafencity, but also draw on sonic continuities. The city's acoustic representation, as well the specific spatial imagination of the city through these motifs, range from colonial activities - such as mission and trade in the late 1900s — all the way to the daily life of the modern city. By connecting these sounds to keywords from a respective discourse, the soundtrack 'Motif'-from How to Hear the Invisible - attempts to depict these sonic continuities and highlight the harbour's significance for German colonialism. The montage of those sounds and site-specific field recordings with spoken information serves to re-signify the denotation of the signature sounds. 'Motif' attempts to trigger 'acts of listening' that realize this process of resignification in one's own cognition. By adding a postcolonial sense to the everyday sonic motives, the daily perception of urban soundscape is being shifted through listening.

\section{Silence}

The harbour itself is not the only example of a location of the intertwining of German colonialism and Hamburg's traders. Other sites of significance, such as the landmark building Afrikahaus, built by the company C. Woermann, or the naming of two streets after the slave-trader Schimmelmann, can be found throughout the city. In this way, perpetrators and beneficiaries of German colonialism have ingrained themselves into the urban image, as well as into the collective memory of the city as local protagonists, while knowledge of anti-colonial resistance or decolonial practices are less visible. An example of such a lack of visibility can be found at the Rothesoodstrasse, near Hamburg's city centre, where the office of George Padmore-an internationally renowned pan-African thinker and activist - had been located up until its destruction by the Nazis in 1933. From his Hamburg office, Padmore organized the international conference of black Workers of the League against Imperialism and published the magazine The Negro Worker. 
Today, this (historical) place is not marked with any information provided to indicate significance. The soundtrack 'Silence' attempts to make Padmore's story audible, as well as to raise awareness for the acoustic phenomenon of silence, by using signal-generated sound materials and working with strong variation of volume. The lack of representation in public spaces and within the collective urban consciousness is a form of silence and can be perceived by listening carefully-and can thus be opened up to discursive interpretation. 'Acts of listening' perceive silence within this context as a certain inaudibility of narrative, and thus recognize the non-sounding of Padmore's story-within the symbolic canon of the city — as a form of not knowing, an omission and exclusion from Hamburg's soundscape and culture of remembrance.

\section{Echo}

The manner in which historic events and the hegemonic perspectives towards them are present in the urban space can be seen clearly in Hafencity. ${ }^{5}$ The acoustics of the district are not only shaped by the materiality of newly constructed building complexes but also by echoes of colonial history. Historic references are present all over the district. While imperialist sailors and conquerors-like Vasco da Gama and Ferdinand Magellan - had already been honoured during German colonialism with their own monument in Hamburg's Speicherstadt, once more we see streets in Hafencity named after them (Informationszentrum 3. Welt, https://www.iz3w.org/zeitschrift/ausgaben/318_grenzen_und_migration/fab). Buildings that have been named after former plantations and colonial commodities - such as Java, Arabica and Silk-might well have been conceptualized with the goal of generating a cosmopolitan 'feel' for the white majority population; however, the city planners failed to recognize and integrate diverse perspectives on global processes, such as migration or a postmigrant urban change, into the shaping of the new district. Due to particular echoes such as these, the Hafencity becomes a space of culture of remembrance in which certain perspectives are being amplified and reinforced while others barely linger. The following quote, taken from an interview with Tania Mancheno, ${ }^{6}$ which forms part of the track Echo, describes this dynamic:

$[\ldots]$ if you look at all these buildings, really, they are all named after plantations. And with these plantations, especially in the awful Überseequartier 
(literally 'overseas district'- a part of the new Hafencity area), you once again encounter an echo. To me, by definition, Übersee divides the world into north and south, rich and poor, black and white, woman and man; all these blatant segregations that once gave justification to allow a large number of people on this planet to be treated as not human. So, the core of racism lie 'overseas' concepts... and we're placing this right in the centre of this city; however because it is also a new centre, a new centre or heart of Hamburg [...] it's, like, again, this longing for exoticism, again another echo and, as already mentioned, all these buildings that have been named after plantations, that were of worldwide significance to Hamburg. Therefore, here is an echo that is based on colonial power, and that does not remotely consider the racism that was justified by its adoption. So ultimately, it is an echo of the civilizatory wound of colonialism. ${ }^{7}$

The soundtrack 'Echo' tries to create an audible playing-out based on the acoustic research about the architectural materiality of the Hafencity, as well as of echo as a sound phenomenon (by using analogous sound effects). Thus, colonial echoes can be experienced in an acoustic, as well as discursive, manner. Through 'acts of listening', it becomes perceivable which perspectives actually resonate in the urban daily life of a postcolonial city.

\section{City and Commemoration as Acoustic Territories}

These examples from How to Hear the Invisible are given in order to show the approach of the project to the memoryscape of Hamburg as an acoustic territory,

[...] specific while being multiple, cut with flows and rhythms, vibrations and echoes, all of which form a sonic discourse that is equally feverish, energetic, and participatory. Sound is shared property onto which many claims are made over time, and which demand associative and relational understanding. (La Belle 2010, p. 24)

With this in mind, listening to the sound tracks reveals the fact that social processes, like the field of remembrance culture, constantly interact with an auditory world, which thus contributes to the experience of the city and its inhabitants. As Stefan Militzer puts it, the act of listening involves the act of 'investigating the origins of a sound and thus becomes an attempt at finding and positioning oneself' (Militzer 2015, p. 68). 
In this sense, the use of the auditory figures in the artistic research aims to understand the city as a realm of contemporary (Motif) and historic (Silence) narratives, and draw attention to the discourse on their representation (Echo). Motif, Silence and Echo function as auditory figures by assigning specific characteristics to spaces and their perception and by giving shape to their specific significance and effects. Thereby, they not only serve to identify a specific acoustic quality, but their effectiveness also allows for identity formation, permits participation and produces exclusions. In this sense, sound phenomena are used to perceive and understand the urban space as a memoryscape, auditory figures add a performative dimension to such sound phenomena beyond their mere semantic meaning. Through their use, How to Hear the Invisible examines the city as a space in which its postcolonial legacy - its consequences and the manner in which it is being dealt with-are manifested acoustically.

The soundtracks transform the significance of spaces and enable possibilities of remembering within the city. In this way, they propose to perceive and discuss the city as a space of remembrance through different ways of listening. The project tries to make the urban space legible as an acoustic one, in which 'sonic materiality operates as "micro-epistemologies", [...] opening up to specific ways of knowing the world' (La Belle 2010, p. 25).

Since they produce and represent cultural modes of signification, the auditory figures of Motif, Silence and Echo serve to analyse Hamburg's memoryscape through sound and by listening. This focus on listening and exploration through acoustic concepts undergoes, in the sense of an acoustic turn, a 'shift away from the privilege of the visible towards an overlooked acoustic dimension' (Meyer 2007, p. 18). According to Petra Meyer, this acoustic turn challenges the paradigm of the visual which, since Plato's Allegory of the Cave (Lee 2003, p. 365) and the subsequent formation of a philosophy that mainly operates with metaphors of light and sight, has dominated European culture. Instead of deeming 'visual coordinates to be the main points of orientation for experience' (Militzer 2015 , p. 70 ), the realm of the acoustic and the act of listening as categories of analysis and experience can be fruitfully applied in artistic research; with this awareness, I adopted the use of sound to reveal obscured dimensions. As I will outline in the following, an acoustic turn can also open up a new perspective with regard to the issue of remembrance culture that, especially in the German context, is usually still conceptualized in mostly visual terms. 


\section{Listening to the Urban Space as a Political Practice}

As I have pointed out through examples from How to Hear the Invisible, listening can alert us to the condition of Hamburg's memoryscape and also enable a political practice of positioning within the city's social structure. By perceiving the tracks, listening becomes a way of decoding and also a way to 'achieve an awareness for the underlying sense (something that is experienced, postulated or aimed at as hidden)' (Barthes 1985, p. 253). By applying this experience to urban space and the local politics of remembrance, listening gains a performative dimension, which I will explain in greater detail by referring to the 'acts of listening' model later on, but first, I want to shed some light on the acoustic sphere of the urban space. It is crucial to acknowledge particular modes of operation, which I want to call the 'surround effect' of the city. While Lefebvre, in his 'rhythmanalysis' (Lefebvre 2004) of the city, presupposes that the listener has to remain outside of the acoustic happening in order to recognize its rhythms, my artistic research identifies the listeners themselves as an essential part of the soundscape of the city. Listeners cannot place themselves outside ofor opposite-the city's soundscape, such as happens when watching a film or looking at a painting. While the act of seeing produces an outside horizon, the act of listening knows no such horizon at all, rendering it impossible for listeners to distance themselves from what is happening; acoustically, we cannot separate ourselves. The city's 'surround effect' therefore always already situates the inhabitants of the city as listeners. The acoustic experience creates positioning in the sense of proximity and distance, as well as political positionality within the city's social context, by paying attention to these questions:

Which sounds are familiar to whom and who can identify with them? How can we articulate and express ourselves? How are we being perceived in the soundscape of the city? To whom do we listen and whom do we try to understand? Who has a voice and what makes a sound?

Which sounds and voices can be perceived and what spaces do they create?

Returning to the opening question regarding forms and possibilities of commemoration as an articulation of citizenship, 'acts of listening' reveal the possibility to politically position one's own sounding in the city and to 
take responsibility for a diverse approach to the city's history through listening. In their essay on postcolonial feminism, Nikita Dhawan and Maria Do Mar Castro Varela introduce the concept of 'subversive listening'. According to the authors, subversive listening is a specific mode of listening in which the listener gains an awareness of her privileges, as well as of the possibility of losing them. Subversive listening thus enables the selfaware subject to refrain from speaking and let others do the talking (Castro Varela and Dhawan 2003, p. 279). In this sense, the soundscape of the postcolonial city, as the basis of the artistic research project How to Hear the Invisible, calls for us to listen in a bi-directional way, which is to say to pay attention to the surrounding space with its atmospheres, noises and linguistic significations, along with its continuities, breaks and silences. Accordingly, this soundscape cannot be deciphered through conventional forms of listening that are still modelled on the linearity of writing, thereby eliminating everything that seems to be insignificant. 'Acts of listening'as a concept explicated in the next section-create a relationship between the subject and the city that is neither selective nor distanced. The listener is always already part of that urban and social space in which commemoration takes place. It is listening that enables the subject to position itself in the debate about adequate forms of postcolonial commemoration.

\section{Acts of Listening and Politics of Sound}

Based on the soundtracks I have discussed, the auditory figures of Motif, Silence and Echo carry political significance because their specific resonance creates a memoryscape of Hamburg. The project How to Hear the Invisible tries to offer an acoustic experience in which this political significance reveals itself only through 'acts of listening'. In this respect, listening is to interpret the sounding out of particular voices and the silencing of certain narratives as a sign of exclusion (silence). Further, listening is to recognize sonic continuities and their significance for the self-conception of the city (motifs). And finally, by acknowledging the political impacts of city planning, listening is to realize neo-colonial echoes within our daily life in Hamburg.

Thus, the examples help to distinguish the difference between hearing and listening. While hearing is predominantly a (passive) perception of sound, listening also implies a form of participating and interpreting. The importance of George Padmore, for example, is not present in the city's narrative, therefore, his story is not audible, but through listening 
it is possible to become aware of its absence, and thus, to comprehend it as silence. In the context of debates about a postcolonial culture of remembrance, listening is one possible approach to the mute urban landscape sketched at the outset, which enables us to experience the gap between the historic past and its aftermath in our daily urban life. Critically, by asking which voices and stories enter common narratives of the city's history and which ones remain mute, the focus on the unheard and the non-sounding can be extended beyond the phenomena of sound to the nonetheless acoustic realm of discourses, standpoints and positionalities.

This dialogue between speaking and listening is based on structures of participation and exclusion that are expressed through vocal phenomena, as I tried to demonstrate with the help of the example of neo-colonial imaginaries echoing in the area of Hafencity. The technique of the montage of both verbal and non-verbal elements used in the project How to Hear the Invisible takes into account that the matter of the research-the dealing with traces of colonial politics in the urban space-is initially inaudible. The 'acoustic dimension of the experience of a certain place cannot be reduced to a simple materiality or a nonbiased hearing' (Fiebig 2015, p. 75). The perception of the sounds and field recordings is itself influenced by the voices of postcolonial protagonists, framing all tracks. Their voices offer the contextualization of the sounds and were also chosen for reasons of representation politics. ${ }^{8}$ Voices and sounds as different acoustic signs are being related to each other when listening. By listening, both the vocal body of the speaker and the listening subject enter into an affective relationship with each other that goes beyond the discursive impact of the interview.

Voice as acoustic material, as well as philosophic phenomena, forms an important part of the research project. As it maintains a productive connection to my original question of the nexus of citizenship and commemoration because, in addition to its appellative attributes, ethical aspects characterize voice. Voice interaction is necessarily marked by a reference to the other; it always establishes a relationship and is fundamentally directed towards somebody else. The conversation is dependent on the other's response, besides different modes of addressing the other. Voices address us in the form of sound-even if we don't understand them. According to Roland Barthes, voice gives us 'instruction' to listen (Barthes 1985, p. 255). This form of address leads to a situation of perception in which silence is just as active and meaningful as speaking: 'listening speaks'. 
I want to apply and broaden this mode of address - in which, according to Barthes, voice is being responded to with 'words or deeds' (Barthes 1985 , p. 255 ) - to a critical discussion of a postcolonial culture of remembrance in Hamburg and outline some theoretical thoughts that evolved through the course of artistic research. I propose a way of listening in which one feels genuinely addressed by non-linguistic acoustic expressions-like continuous motifs, neo-colonial echoes and discursive silenceas much as by voice-based signals. The idea of 'acts of listening' is an attempt to acknowledge these different acoustic forms of address. In this way, listening constitutes an acoustic space in which different sounds, with their respective levels of meaning, work in a performative way. Through 'acts of listening', those levels of meaning are channelled, and an acoustic space is created in which Motif, Silence and Echo-as auditory figurescall for us to listen as a way of reworking history and a form of commemoration. If listening 'speaks' to us, as Barthes put it, then the experience of this acoustic space requires translation: translation of sound and voices into a social experience of the postcolonial Hamburg, as well as translation of an acoustic relationship into knowledge about the city. This translation relates to a process of interpretive participation. 'Acts of listening' increase the sensitivity to the postcolonial in the city. Thus, to listen also means to feel addressed and to transfer this address into conceptual and aesthetic categories. In this sense, it is not only the speech act that constitutes a performative, but also the act of listening.

\section{Acoustic Remembrance and Performative History WRITING}

As illustrated, listening is not a given phenomenon that works in nonpolitical or trans-historical ways. Sound is associative and ephemeral in nature, but it is also an essential component of the world it participates in and constructs. For Brandon LaBelle, sound 'comes to reconfigure the spatial distinctions of inside and outside, to foster confrontations between one and another, and to infuse language with degrees of immediacy' (LaBelle 2010, p. xxi). Therefore, listening produces spaces and social materialities, and it thus intervenes in the field of the visible. Precisely the associative character of sound makes it inherently political-which sounds we hear, and how we hear them is open for interpretation, and therefore, a political issue. The knowledge and the experience that we 
associatively generate through sound lead to modes of awareness other than seeing.

Thus, one aim of the artistic research, How to Hear the Invisible, is to facilitate a knowledge production beyond the familiar ways of perception. Dealing with sound is in this way a matter of dealing with the processes of decoding and identifying. While listening is connected with normative notions and criteria, at the same time, it is able to inspire our imagination in different ways. 'Acts of listening' enable a critical engagement with the 'subconscious ideological structures (of the language, thinking and experience) which guide our knowledge and our actions (Hall 2004, p. 145).' Stuart Hall describes representation as the power 'to label, give meaning to or classify someone or something'. It is precisely this form of power that can potentially be undermined by non-visual practices such as listening. 'Acts of listening' thus encompass a critical mode towards normative discourse that impacts our visual perception. If we understand such politics of representation as a set of notions, realizations and political stand-ins, then 'acts of listening' can fragment their structure and quality, and unfold it through different forms of perception and imagination in a productive way.

Returning to the project, the idea of How to Hear the Invisible is to make various fragments of space and its history audible; the soundtracks reinforce different forms of listening and enable a change of perspective in the current perception of the city and its history. In this case,

[...] the temporality of the location is no longer a mere continuity - it becomes an experience of constellations, disruptions, asynchronicities and consequentially demands the listener to question their own role as contemporary and as witness. Listening may have always been an associative act, an associative happening, but only specific media-based or artistic approaches activate the different aesthetic, political and social potentials of association. (Albrecht and Wehren 2015, p. 13)

Thus, the access to history remains fragmentary and develops only in the listener's specific and subjective imagination. Imagination in this context means the ability to conjure up something which is absent. This imagination is always specifically situated and applicable to one's own reality. Imagination in the context of a postcolonial culture of remembrance means approaching events from the colonial history with a certain kind of awareness. From today's perspective, one can only begin to fathom the violent nature, rather than fully comprehending it. The attempt to under- 
stand this history also always depends one's own social positioning. In this sense, How to Hear the Invisible tries to enable 'acts of listening' that can play a part in decolonial politics within the urban space: by critically examining representation, by promoting awareness for motif, silence and echoes and by encouraging one to deal with the consequences and aftermath of colonial politics. The project proposes a practice of remembering where 'acts of listening' use our sonic memory, and today's city, as the starting point of a performative historiography through sound. In the context of a postcolonial culture of remembrance, it is a productive challenge for a critical historiography to examine its own concept of culture. The soundtracks produced and the concept of 'acts of listening', developed within the frame of the artistic research, form an attempt to broaden the range of the culture of remembrance-traditionally dominated by written and monumental concepts. How to Hear the Invisible demands a practice of remembering and a historiography that repeatedly questions, contests and challenges their ways of transferring knowledge.

The project comprehends listening as a practice of cultural remembrance (erinnerungskulturell) and a performance of citizenship. Using sound as a medium, and triggering 'acts of listening', makes possible specific orders of relationship between the city's inhabitants as senders and receivers. Here, an intersubjective space emerges that allows for a specific form of commemoration. Performing citizenship means experimenting with the political potential of sound in the sense of experimenting with modes of listening, which create a new sociality in, and new perspectives on, the city. Speaking with Gerald Fiebig, new sociality here means to overcome 'the formation of identity in the metropolis according to predefined actions, functions and occupations'. 'Acts of listening' do not only lead to the sounds and voices themselves but, as Fiebig puts it, they enable an encounter with 'categories of experience and identity; with questions of the naturalness of normality of a class of activities; and with other selves engaged in their own categories, experiences, questions and activities' (Fiebig 2015, p. 80).

Therefore, listening - as one mode of working through and commemorating historical events, and thus, a critical way of performing citizenship-has the potential to mark the city as postcolonial, following the traces of the unheard within the heard, of the unknown within the known; becoming aware of one's own position within it. 'Acts of listening' triggered by artistic work with sound are 'a form of listening that allows for switching between different frames of reference: a mode of listening of 
many modes of reading' (Ungeheuer 2002, p. 205). They can help us to understand the urban community in a different way and to reconfigure it - as location and de-location of sounds and voices that offer alternative historical and political perspectives with formerly unacknowledged dimensions, and also act as an undermining of orders of representation. Acoustic forms of commemoration thus allow for different forms of listening, of speaking and of sounding, as social practices within the postcolonial city. It might even be used to create a new imagination of the city, as an urban and social practice of perception, and so, reformulating commemoration as a performance of citizenship.

\section{Notes}

1. Artist and curator Hannimari Jokinen, interviewed by Katharina Kellermann, April 2016 (translated by author).

2. In this context, the author of this article acknowledges that she is white, and thus benefits from a host of social privileges. Her privileged position affects both the artistic and scientific, as well as the activist perspective on the subject.

3. These audio tracks are available on the website: www.how-to-hear-the-invisible.org

4. Artistic Research Project How to Hear the Invisible (2017). The following is an excerpt transcribed from the track 'Motif':

Hamburg - the city. It's harbour - Bismarck memoria - 'Colonial capital of the German Empire'. Berlin Conference. Africa Conference $1884-$ Colonialization of Africa - Cameroon, Toga, today's Namibia - as the German South West Africa - as well as today's Tanzania, Rwanda and Burundi - as German East Africa. - Also German New Guinea, Samoa, Kiautschou - Resistance - Rudolf Duala Manga Bell - Mpondo AkwaResistance. - In Duala 1884 - At the 'Waterberg' 1904 - the Maji Maji from 1905 on. - Violent counter-insurgency by German soldiers.

5. Hafencity is Hamburg's newest district, in development since 2008.

6. Tania Mancheno is a historian and a cultural worker living in Hamburg. She developed critical city tours through Hafencity and Speicherstadt, dealing with the colonial history of Hamburg. The term 'echo' I borrowed from the tour: 'Hafencity Inbetween Cosmopolitan Flairs and Colonial Echoes' (conducted by Tania Mancheno and the city planer Andreas Schneider). Their valuable contribution to this research is acknowledged with thanks.

7. Tania Mancheno, interviewed by Katharina Kellermann, February 2016 (translated by author). 
8. All interviewees-Millicent Adjei, HMJokinen, Israel Kaunatjike, Tania Mancheno and Andreas Schneider-are members of the groups that signed the open letter: 'Not about us without us'. Under this slogan, various civil societal groups and communities have commented on their exclusion from the proposals of the Hamburg Senate for the reworking of the colonial heritage of the city, and called for participation. See also their open letter: http://www.hamburg-postkolonial.de/PDF/PM_NOTWITHOUTUS. pdf, date accessed 4 January 2017.

\section{REFERENCES}

Albrecht, M., and M. Wehren. 2015. Verortungen/Entortungen. Urbane Klangräume und die Frage nach einer Politik des Sounds. In Verortungen Entortungen: urbane Klangräume, ed. M. Albrecht and M. Wehren. Berlin: Neofelis.

Barthes, R. 1985. The Responsibility of Forms. New York: Hill and Wang.

Castro Varela, M., and N. Dhawan. 2003. Postkolonialer Feminismus und die Kunst der Selbstkritik. In Spricht die Subalterne deutsch? Migration und postkoloniale Kritik, ed. E. Rodriguez and H. Steyerl. Münster: Unrast.

Fiebig, G. 2015. Soundscape und Aura. Zur Verortung und Entortung von Soundscapes in der zeitgenössischen Audiokunst. In Verortungen-Entortungen: urbane Klangräume, ed. M. Albrecht and M. Wehren. Berlin: Neofelis.

Hall, S. 2004. Das Spektakel des >Anderen<. In Ideologie, Identität, Repräsentation Ausgewählte Schriften 4, ed. S. Hall. Hamburg: Argument.

LaBelle, B. 2010. Acoustic Territories: Sound Culture and Everyday Life. New York: Continuum Books.

Lee, Desmond, ed. 2003. Plato. The Republic. London: Penguin.

Lefebvre, H. 1991. The Production of Space. Oxford: Blackwell.

- 2004. Rhythmanalysis: Space, Time and Everyday Life. London: Continuum.

Meyer, P. 2007. Acoustic Turn. Paderborn: Fink.

Militzer, S. 2015. Der Klang der Stadt. Ansätze zu einer Phänomenologie des urbanen Hörens. In Verortungen - Entortungen: urbane Klangräume, ed. M. Albrecht and M. Wehren. Berlin: Neofelis.

Möhle, H., S. Heyn, and S. Lewerenz, eds. 2006. Zwischen Völkerschau und Kolonialinstitut. AfrikanerInnen im kolonialen Hamburg. Hamburg: Eine Welt Netzwerk Hamburg e.v. und St.Pauli Archiv.

Nora, P. 2010. Les Lieux De Mémoire, Volume 4: Histories and Memories. Chicago: The University of Chicago Press.

Ranciere, J. 2004. The Politics of Aesthetics: The Distribution of the Sensible. London and New York: Continuum.

Schafer, R. 1977. The Tuning of the World. New York: Alfred A. Knopf.

Ungeheuer, E., ed. 2002. Elektroakustische Musik. Laaber: Laaber. 


\section{WEBLINKS}

Arbeitskreis Hamburg Postkolonial. 2017a. http://www.hamburg-postkolonial. de/PDF/PM_NOTWITHOUTUS.pdf. Accessed 18 Jan 2017.

_ 2017b. https://hhpostkolonial.files.wordpress.com/2014/07/senatsbericht-koloniales-erbe2014.pdf. Accessed 12 Feb. 2017.

—. 2017c. http://www.hamburg-postkolonial.de/PDF/Stadtrundgaenge HafenrundfahrtenHamburg2016.pdf. Accessed 12 Feb 2017.

Artistic Research Project How to hear the invisible. 2017. http://how-to-hear-theinvisible.org. Accessed 18 Jan 2017.

Graudiertenkolleg Performing Citizenship. 2017. http://performingcitizenship. de/data/katharina-kellermann-forschungsprojekt/. 18 Jan 2017.

Informationszentrum 3. Welt. 2017. https://www.iz3w.org/zeitschrift/ausgaben/318_grenzen_und_migration/fab. Accessed 18 Jan 2017.

Open Access This chapter is licensed under the terms of the Creative Commons Attribution 4.0 International License (http://creativecommons.org/licenses/ by $/ 4.0 /)$, which permits use, sharing, adaptation, distribution and reproduction in any medium or format, as long as you give appropriate credit to the original author(s) and the source, provide a link to the Creative Commons licence and indicate if changes were made.

The images or other third party material in this chapter are included in the chapter's Creative Commons licence, unless indicated otherwise in a credit line to the material. If material is not included in the chapter's Creative Commons licence and your intended use is not permitted by statutory regulation or exceeds the permitted use, you will need to obtain permission directly from the copyright holder.

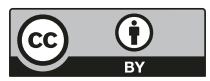

